Scientific journal

\section{PHYSICAL AND MATHEMATICAL EDUCATION}

Has been issued since 2013.

Науковий журнал

ФІЗИКО-МАТЕМАТИЧНА ОСВІТА

Видається з 2013.
ISSN 2413-158X (online)

ISSN 2413-1571 (print)

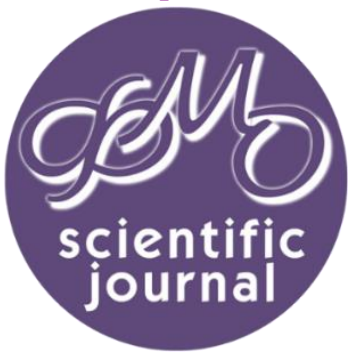

Семеног О.М. Методична підготовка майбутніх учителів-словесників до формування в учнів основ підприємливості та ініціативності. Фізико-математична освіта. 2019. Випуск 3(21). С. 133-139.

Semenog 0 . Methodical preparation of future language-teachers for the students' entrepreneurship and initiative basis formation. Physical and Mathematical Education. 2019. Issue 3(21). P. 133-139.

DOI 10.31110/2413-1571-2019-021-3-020

О.М. Семеног

Сумський державний педагогічний університет імені А.С. Макаренка, Україна olenasemenog@gmail.com

ORCID: 0000-0002-8697-8602

\author{
МЕТОДИЧНА ПІДГОТОВКА МАЙБУТНІХ УЧИТЕЛІВ-СЛОВЕСНИКІВ \\ ДО ФОРМУВАННЯ В УЧНІВ ОСНОВ ПІДПРИЄМЛИВОСТІ ТА ІНІЦІАТИВНОСТІ
}

АНОТАЦІЯ

Здійснено огляд наукових напрацювань щодо методичної підготовки майбутніх учителів-словесників до реалізації наскрізної змістової лінії «Підприємливість і фінансова грамотність» на уроках української мови у старшій школі, формування в учнів однієї із ключових компетентностей з основ підприємливості та ініціативності.

Формулювання проблеми. Відповідно до статmі 12 Закону України «Про освіту» (2017) мету повної загальної середньої освіти визначено як всебічний розвиток, виховання і сочіалізацію особистості, яка здатна до життя в суспільстві та цивілізованої взаємодії з природою, має прагнення до самовдосконалення і навчання впродовж життя, готова до свідомого життєвого вибору та самореалізації, відповідальності, трудової діяльності та громадянської активності. Досягнення мети забезпечується через наскрізні для шкільних програм всіх начальних предметів змістові лінії, до яких віднесено і «Підприємливість і фінансову грамотність». Реалізувати означену наскрізну змістову лінію пропонується шляхом формування однієї із ключових компетентностей, необхідних для успішної життєдіяльності, компетентності «ініціативність і підприємливість». Упровадження наскрізної змістової лінії «Підприємливість $і$ фінансова грамотність» у навчальні предмети “українська мова» й “українська література» передбачає виконання міжпредметних навчальних проектів, роботу учнів з різними джерелами інформації з метою формування умінь ясно і переконливо говорити, презентувати власні плани, чітко ставити завдання, планувати, розв'язувати конфліктні ситуації, приймати рішення, брати на себе відповідальність, формувати моделі поведінки, необхідні для успішного розв'язання виробничих проблем. Такі вимоги потребують від учителів-словесників постійного особистісного $і$ професійного розвитку й саморозвитку, що на етапі навчання в закладах вищої педагогічної освіти забезпечується, зокрема, уведенням до професійно орієнтованих, методичних дисциплін тем «Ключові компетентності школяра Нової української школи».

Матеріали і методи. Теоретичні та емпіричні методи: аналіз, узагальнення та систематизація довідникових, наукових джерел з метою уточнення сутності ключових понять, виявлення стану розробленості означеної проблеми.

Результати. Акцентована увага на окремих аспектів методичної підготовки майбутніх учителів-словесників до формування в учнів основ підприємливості та ініціативності. Узагальнено європейські та українські законодавчо-нормативні освітні документи, здійснено огляд шкільних програм та методичного забезпечення деяких шкільних підручників з української мови для учнів 10 класу, запропонованого для реалізації наскрізної лінії «Підприємливість і фрінансова грамотність» та формування компетентності «ініціативність і підприємливість» на уроках української мови, аналіз яких передбачається на заняттях з мовно-методичних курсів у вищій школі.

Висновки. В умовах реформування загальної середньої освіти й утвердження особистісно орієнтованої моделі освіти актуалізується потреба уведення до професійно орієнтованих, методичних дисциплін в закладах вищої педагогічної освіти теми "Ключові компетентності школяра Нової української школи», з-поміж яких важливе місце відведено підприємницькій компетентності або компетентності «ініціативність і підприємливість». Перспективним напрямом подальшого дослідження буде аналіз виконаних студентами проектів, спрямованих на формування в учнів основ підприємливості та ініціативності.

КЛЮчОвІ СлОВА: мовно-методичний курс, майбутній учитель-словесник, студент, учень, старша школа, урок української мови, заклад вищої педагогічної освіти, шкільна програма, підручник з української мови, підприємницька компетентність учня, компетентність " підприємливість та ініціативність».

ВСТУП

Постановка проблеми. Відповідно до статті 12 Закону України «Про освіту» (2017) (Про освіту, 2017) мету повної загальної середньої освіти визначено як всебічний розвиток, виховання і соціалізація особистості, яка здатна до життя в суспільстві та цивілізованої взаємодії з природою, має прагнення до самовдосконалення і навчання впродовж життя, 
готова до свідомого життєвого вибору та самореалізації, відповідальності, трудової діяльності та громадянської активності. Досягнення мети забезпечується через наскрізні для шкільних програм всіх начальних предметів змістові лінії, що виступають засобом інтеграції ключових і загальнопредметних компетентностей, навчальних предметів та предметних циклів. Зокрема, вивчення наскрізної лінії «Підприємливість іфінансова грамотність», зазначається в документі, забезпечить краще розуміння молодим поколінням українців практичних аспектів фінансових питань (здійснення заощаджень, інвестування, запозичення, страхування, кредитування тощо); сприятиме розвиткові лідерських ініціатив, здатності успішно діяти в технологічному швидкозмінному середовищі.

Реалізувати наскрізні змістові лінії пропонується шляхом формування ключових компетентностей, необхідних для успішної життєдіяльності, з-поміж яких визначають і компетентність «ініціативність і підприємливість» як уміння генерувати нові ідеї й ініціативи та втілювати їх у життя з метою підвищення як власного соціального статусу та добробуту, так і розвитку суспільства і держави; вміння раціонально вести себе як споживач, ефективно використовувати індивідуальні заощадження, приймати доцільні рішення у сфері зайнятості, фінансів тощо. Засобами кожного шкільного предмету учитель має готувати учнівську молодь до активного професійного життя, що сприятиме підвищенню їхньої конкурентоспроможності на ринку праці. Такі вимоги потребують від учителів різних предметів постійного особистісного і професійного розвитку й саморозвитку, що на етапі навчання в закладах вищої педагогічної освіти забезпечується уведенням до професійно орієнтованих, методичних дисциплін тем «Ключові компетентності школяра Нової української школи».

Мета наскрізної лінії «Підприємливість і фінансова грамотність» - навчання молодого покоління українців ощадливості, раціонального використання коштів, планування витрат, стимулювання у них лідерських ініціатив, прагнення успішно діяти в технологічному швидкозмінному середовищі, - читаємо у шкільній програмі з української мови для учнів 5-9 класів (Українська мова. 5-9 класи, 2016). У документі наголошується на важливості умінь презентувати власні ідеї та ініціативи зрозуміло, грамотно, використовуючи доцільні виражальні мовні засоби; використовувати ефективні комунікативні стратегії для формулювання власних пропозицій; самоорганізовуватися; оцінювати економічні ініціативи та економічну діяльність, проявляти готовність брати на себе відповідальність; розуміння ролі комунікативних умінь для успішної професійної кар'єри. 3 цією метою пропонуються, зокрема, такі навчальні ресурси, як тексти, що містять моделі ініціативності; ділові папери (план роботи, звіт, резюме, заява тощо), самопрезентація, зразки реклами. У програмах з української мови для старших класів компетентність «ініціативність підприємливість» охарактеризовано як уміння генерувати нові ідеї й ініціативи та втілювати їх у життя з метою підвищення як власного соціального статусу та добробуту, так і розвитку суспільства і держави; вміння раціонально вести себе як споживач, ефективно використовувати індивідуальні заощадження, приймати доцільні рішення у сфері зайнятості, фінансів тощо, а до навчальних ресурсів віднесено тексти офіційно-ділового стилю (резюме, доручення тощо), самопрезентації, зразки реклами, літературні твори, які містять моделі ініціативності. Робота із текстами значною мірою сприяє формуванню основ підприємницької компетентності учнів контексті сучасних вимог до мовної освіти.

Аналіз актуальних досліджень. Актуальні проблеми підприємницької діяльності і підприємницької підготовки, формування підприємницької компетентності в українській освіті в останні роки є предметом досліджень В. Андріанової, 3. Гіптерс, Г. Назаренко, В. Майковської, О. Романовського, В. Шабанової та ін. Питання мовно-методичної підготовки майбутніх учителів-словесників досліджують М. Вашуленко, О.Горошкіна, Л. Мацько, А. Нікітіна, С. Караман, В. Мельничайко, С. Омельчук, Н. Остапенко, М. Пентилюк, Т. Симоненко, Л. Струганець та ін. Розгляд окремих питань роботи вчителів-словесників з дітьми щодо формування в них підприємницької компетентності, проведення уроків з підприємницьким тлом представлено у статті Л. Гончаренко (Гончаренко Л. А., 2016). Методичні поради щодо формування основ підприємницької компетентності учнів на уроках економіки, основ підприємництва, біології, хімії, української мови, образотворчого мистецтва тощо, конспекти уроків із підприємницьким тлом, що їх розробили українські вчителі в рамках українсько-польського проекту «Уроки з підприємницьким тлом» (2014р.), представлено в посібниках (Назаренко Г. А., 2014; Уроки з підприємницьким тлом, 2014). Означені питання є предметом обговорення на конференціях та семінарах. Напрацьований теоретичний і практичний досвід слугує підгрунтям методичної підготовки майбутніх учителів-словесників у закладах вищої педагогічної освіти до формування в учнів компетентності з основ підприємливості та ініціативності.

Мета статті. У межах статті акцентуємо дослідницьку увагу на окремі аспекти методичної підготовки майбутніх учителів-словесників до формування в учнів основ підприємливості та ініціативності; узагальнимо європейські та українські законодавчо-нормативні освітні документи, здійснимо огляд шкільних програм та методичного забезпечення деяких шкільних підручників з української мови для учнів 10 класу, запропонованого для реалізації наскрізної лінії «Підприємливість і фінансова грамотність» та формування компетентності «ініціативність і підприємливість» на уроках української мови.

\section{МЕТОДИ ДОСЛІДЖЕННЯ}

Для досягнення мети використано такі методи: аналіз, узагальнення, систематизація наукових джерел та методичного забезпечення з метою виявлення стану розробленості проблеми мовно-методичної підготовки майбутніх учителів-словесників до формування в учнів основ підприємливості та ініціативності.

\section{РЕЗУЛЬТАТИ ДОСЛІДЖЕННЯ}

Зазначимо, що у статті (Семеног О.М., 2018) нами здійснено огляд наукових напрацювань щодо концепту «підприємницька компетентність» на засадах лінгвопраксеологічного підходу. На основі аналізу довідникових та наукових джерел крізь призму лінгвопраксеології окреслено поняття «підприємництво», «підприємливість», «бізнес»», «підприємець», "успішна людина». Акцентовано увагу на особистісно-комунікативному компоненті підприємницької компетентності. Ідеться, зокрема, про вміння налагоджувати контакт з клієнтами, вибір доцільного варіанта мовленнєвої 
поведінки; орієнтуватися в типових і нетипових ситуаціях професійного спілкування, про культуру підприємництва, що $€$ складниками організаційної лінгвістики. Керуємось такою характеристикою і в цьому дослідженні.

На заняттях з мовно-методичних курсів у вищій школі з'ясовуємо, зокрема, сутність поняття «ініціативність і підприємливість» у європейських документах. Як показує аналіз Рекомендацій Європарламенту і Ради Європи «Ключові компетентності для навчання впродовж життя (Key Competences for Lifelong Learning A European Reference Framework, 2006), підприємницьку компетентність (Entrepreneurship competence) або ініціативність і підприємливість у 2006 р. уведено до переліку ключових і визначено як здатність втілювати ідеї, що генерують цінність для інших, а не лише для себе самого, в певні дії, як наскрізну ключову компетентність, необхідну кожному громадянину для самореалізації та розвитку, активної громадянської позиції, суспільної інтеграції та зайнятості в суспільстві, що ґрунтується на знаннях.

у Звіті Eurydice щодо «Навчання підприємливості у навчальних закладах» (2016) узагальнено, що близько половини країн Європи користуються визначенням підприємливості, поданим вище; третина країн використовують власне національне визначення, а 10 країн не мають узгодженого визначення на національному рівні (цит. за Bacigalupo M., Kampylis P., Punie Y., Van den Brande G., 2016). У звіті зазначено відсутність всеохопних результатів навчання підприємливості як одну з основних перешкод для розвитку навчання підприємливості в Європі, тому однією 3 ключових цілей EntreComp $€$ розробка спільного концептуального підходу до розвитку підприємливості на європейському рівні. Європейська спільнота користується і терміном «компетентність підприємливості». Зокрема, EntreComp визначає підприємливість як поняття, що грунтується на створенні культурної, соціальної чи економічної цінності, виділяє різні види підприємництва, у тому числі внутрішньоорганізаційне, соціальне, «зелене» підприємництво, а також підприємництво у сфері інформаційних технологій. Рамка EntreComp, представлена у документі, ґрунтується на широкому розумінні підприємливості, яке включає в себе «ініціативність».

В умовах реформування загальної середньої освіти «Нова українська школа», утвердження особистісно орієнтованої моделі освіти актуалізується потреба формування учнівської молоді як активних, підприємливих і відповідальних громадян. Відповідно до Державного стандарту базової і повної загальної середньої освіти (Державний стандарт базової і повної загальної середньої освіти, 2011) формування підприємницької компетентності передбачено в реалізації здатності учнів співвідносити власні економічні інтереси й потреби з наявними ресурсами, інтересами і потребами інших людей та суспільства; організовувати власну трудову та підприємницьку діяльність та працю колективу, орієнтуватися в нормах і етиці трудових відносин; аналізувати й оцінювати власні професійні можливості, здібності й співвідносити їх з потребами ринку праці; складати, здійснювати й оцінювати плани підприємницької діяльності та особисті бізнес-проекти; презентувати та поширювати інформацію про результати власної економічної діяльності та діяльності колективу.

У проекті Державного стандарту базової середньої освіти (2019) (Державний стандарт базової середньої освіти, 2019), що наразі обговорюється, на позначення ключової компетентності уживаний термін «підприємливість та фінансова грамотність»; ідеться про ініціативність, спроможність використовувати можливості та реалізовувати ідеї, перетворюючи їх на цінності для інших, уміння вирішувати проблеми, готовність брати відповідальність за власні рішення, здатність працювати в команді заради планування та здійснення проєктів, які мають культурну, суспільну або комерційну цінність.

На практичних заняттях з мовно-методичних курсів Сумського державного педагогічного університету імені А.С. Макаренка зі студентами та магістрантами узагальнюємо європейські та українські законодавчо-нормативні освітні документи, здійснюємо також огляд шкільних програм та шкільних підручників з української мови, запропонованого для реалізації наскрізної лінії «Підприємливість і фінансова грамотність» та формування компетентності «ініціативність і підприємливість», вивчаємо досвід педагогів, які активно напрацьовують методичне забезпечення з формування у школярів підприємливості та фінансової грамотності. Це сприяє, як показують результати занять і педагогічної практики, розвитку й у студентів і магістрантів умінь генерувати нові ідеї й ініціативи та втілювати їх у життя з метою підвищення як власного соціального статусу та добробуту, так і розвитку суспільства і держави; умінь конструктивно спілкуватися в колективі, проявляти лідерські якості; реагувати мовними засобами на спектр соціальних і культурних явищ, попереджувати і розв'язувати конфлікти, досягати компромісів; конструктивно керувати емоціями; адаптовуватися до нових умов, вирішувати нестандартні завдання; працювати в групі, в команді.

\section{ОБГОВОРЕННЯ}

Питання методичної підготовки майбутніх учителів-словесників до формування в учнів основ підприємливості та ініціативності, шкільні програми та методичне забезпечення шкільних підручників з української мови, запропонованого для реалізації наскрізної лінії «Підприємливість і фінансова грамотність» та формування компетентності «ініціативність і підприємливість» на уроках української мови, обговорювалось на засіданнях ресурсного центру кафедри української мови і літератури Сумського державного педагогічного університету імені А.С.Макаренка. Якісній роботі на заняттях сприяє і робота аспірантів та докторантів кафедри української мови і літератури, зокрема В.Майковської (В.Майковська, 2017). Дослідниця систематизувала методичне забезпечення і проаналізувала програми курсів для учнів молодшого шкільного віку («Початки економіки», «Робочий зошит з економіки» (розробник - О. Варецька); “Цікава економіка» (Л. Кашуба); «Школа бізнесу: 1-4 клас» (В. Акуліна, Н. Капінус, О. Куріпко, Л. Ткач), що підготовлені з метою формування умінь раціонально використовувати матеріал, об'єктивно оцінювати результати праці, чесно та сумлінно ставитися до своїх обов'язків, а одним із засобів формування підприємницької компетентності молодших школярів $\epsilon$ підготовка і проведення комплексних навчально-економічних екскурсій до комерційних суб'єктів ринку (Майковська В. І., 2017). Для учнів основної та старшої школи, зазначає В.Майковська, запропоновано «Початки економіки» (розробник О. Варецька); «Економіка» (Ю. Лелюк, О. Решетняк, І.Тимченко, Т. Чорна); «Економіка» (Б. Бобров, Г. Ковальчук, В. Мельничук, В. Огнев'юк, О. Часникова); «Географія світового господарства з основами економіки» для учнів 11 класу» (Г. Ковальчук); «Комерційна географія» (М. Сорока); «Фінансова математика» (Ю. Бицюра); «Трудове навчання. Основи підприємницької діяльності» (О. Грєбєннікова та Л. Яцунь), «Основи менеджменту» (Г. Горленко), «Клієнт банку» 
(Г. Горленко, К. Горленко). Загалом, слушно зауважує В.Майковська, методики формування фахової компетентності 3 основ підприємництва пропонуються переважно для майбутніх вчителів технологій та математики і загалом відсутні для вчителів гуманітарних дисциплін.

Зі студентами аналізуємо шкільні програми 3 акцентом на реалізацію наскрізної лінії «Підприємливість і фінансова грамотність» та формування компетентності «ініціативність і підприємливість» на уроках української мови. Зокрема, програма для загальноосвітніх навчальних закладів з українською мовою навчання (рівень стандарту, 10-11 класи; автори - Голуб Н.Б., Котусенко О.Ю., Горошкіна О.М., Новосьолова В.І та ін.) (Програма «Українська мова. 10-11 класи». рівень стандарту, 2018) пропонує мету наскрізної лінії «Підприємливість і фінансова грамотність» спрямувати на навчання молодого покоління українців ощадливості, раціонального використання коштів, планування витрат, стимулювання у них лідерських ініціатив, прагнення успішно діяти в технологічному швидкозмінному середовищі, а ключову компетентність «Ініціативність і підприємливість» розглядати як інтегровану якість особистості, що базується на креативності, творчості, інноваційності, здатності до ризику, спроможності планувати, самоорганізовуватися й організовувати підприємницьку діяльність, утілювати ідеї у сферу економічного життя, розв'язувати конфліктні ситуації, приймати рішення, брати на себе відповідальність, формувати моделі поведінки, необхідні для успішного розв'язання нагальних виробничих проблем.

Укладачі програми пропонують активніше залучати учнів до завдань, що стимулюють формування умінь презентувати власні ідеї та ініціативи зрозуміло, грамотно, використовуючи доцільні мовні засоби; використовувати комунікативні стратегії для формулювання власних пропозицій і рішень і виявлення лідерських якостей; оцінювати економічні ініціативи та економічну діяльність; проявляти готовність брати відповідальність за себе та інших. Для учнів 10 класу укладено такі соціокультурні теми: Піклування про власний розвиток; Активна участь у житті суспільства; Формула успіху людини; Доброчинність як найбільша цінність і шанована риса лідера; Планування фінансового добробуту; Переваги, загрози, недоліки улюбленої справи; Фінансовий контроль; Відповідальність за фінансові проблеми в родині; Піклування про саморозвиток як активний внесок у розвиток суспільства; Як заробляти гроші у шкільному віці; Вчитися розпоряджатися грошима; Боргова пастка; Мої заощадження; Фінансова відповідальність кожного; Планування власного бюджету; Планування бюджету колективної мандрівки; Петро Яцик - українець, який відмовився бути бідним; Розуміння багатства і бідності; Визнання права власності й повага до нього; Ініціативність як здатність людини самостійно започаткувати свою справу; Майстри своєї справи; Фінансові заощадження як ознака фінансової грамотності; Спільна діяльність; Розподіл обов'язків і відповідальності.

Для формування компетентності «ініціативність і підприємливість» на уроках української мови в 11 класі призначено теми Мовний етикет фахівця; Історія одного успіху; Виховання потреби враховувати інтереси й особливост своїх партнерів; Інноваційність і творчість - передумова успіху; Повага до чүжої власності; Підприємливість у приказках народів світу; Підприємливість літературних героїв; Підприємливість, гідна наслідування; Корисні звички й цінні риси підприємливої людини; Способи виходу з конфліктів; Ставлення до невдач; Без довіри бізнес не розвивається; Поразки в бізнесі мають загартовувати і спонукати мислити й навчатися; Гарні стосунки з людьми - запорука успіху; Вчимося працювати ефективно й результативно; Підприємницька спритність; Пунктуальність як риса підприємця; Уміння робити висновки з помилок.

Програма для загальноосвітніх навчальних закладів з українською мовою навчання (філологічний напрям, профіль - українська філологія, 10-11 класи; автори - Мацько Л.І., Груба Т.Л., Семеног О.М., Симоненко Т.В.) (Українська мова. 10-11 класи, 2017) визначає потребу в опануванні учнями таких тем, як Доброчинність як цінність; Фінансовий добробут; Фінансова відповідальність кожного; Саморозвиток особистості; Планування бюджету колективної мандрівки; Фінансові заощадження як ознака фінансової грамотності; Спільна діяльність (10 клас); Інноваційність і гуманність як передумова успіху; Корисні звички; Підприємливість і довіра; пунктуальність(11 клас).

Для досягнення запланованих завдань, слушно зауважує Гончаренко Л. (Гончаренко Л., 2014), педагоги можуть використовувати різні завдання: створити рекламу товару, написати резюме і заяву на влаштування на роботу, на уроках зв'язного мовлення доцільними є техніки «мозкового штурму», роботи в групі, парі, презентації, що спрямовані на розвиток знань, умінь, навичок, цінностей, особистісних якостей. На практичних заняттях зі студентами Сумського державного педагогічного університету імені А.С. Макаренка аналізуємо шкільні підручники під кутом реалізації наскрізної лінії «Підприємливість і фінансова грамотність» та формування компетентності «ініціативність і підприємливість» на уроках української мови.

Проведений аналіз підручника «Українська мова. рівень стандарту (автори - Заболотний О.В., Заболотний В.В.) для учнів 10 класу закладів загальної середньої освіти (Заболотний О.В., Заболотний В.В., 2018) засвідчує наявність вправ, що передбачають роботу зі словниками, характеристику окремих понять наскрізної лінії «Підприємливість і фінансова грамотність»:

- Зіставте подані тлумачення слів бізнес, бізнесмен, узяті з різних лексикографічних джерел. Поміркуйте, які із цих тлумачень виписано зі «Словника української мови» в 11-ти томах (1970-1980), а які - зі «Словника української мови» в 20-ти томах (2010-2017). Відповідь обгрунтуйте.

Бізнес... розм. Комерційна, біржова або підприємницька діяльність як джерело наживи...

Бізнесмен... Великий ділок, комерсант, підприємець...

Бізнес... 1. Підприємницька діяльність, спрямована на отримання прибутку... 2. збірн. Бізнесмени, підприємці... Зробити бізнес..

Бізнесмен... Людина, яка займається комерційною діяльністю, бізнесом; підприємець..

- Прочитайте текст. Чи згодні ви з висловленням Джима Рона? Обгрунтуйте свою думку. МАРКЕТИНГ

За висловленням відомого психолога, філософа у сфері бізнесу Джи ма Рона, успіх складається на 20 \% із вашого досвіду й кваліфікації та на 80 \% - із вибраної вами стратегії дій. Успіх маркетингової діяльності значною мірою залежить від працівників маркетингових служб, які безпосередньо контактують з покупцями. Якими ж якостями мають бути 
наділені ці працівники? Маркетологи виділяють такі: цілеспрямованість, енергійність, наполегливість, розвинений інтелект, доброзичливість, уміння спілкуватися з людьми, здатність перейматися почуттями клієнтів, коректність, уміння одягатися відповідно до обставин...

Що ж хочуть покупці від продавців, а разом з ними й від виробників? По-перше, придбання якісного товару за прийнятними цінами, виробу модного, надійного, довговічного, зручного в користуванні, безпечного, з гарним дизайном і упаковкою. По-друге, компетентності, уважного і ввічливого ставлення до себе під час вибору товару. Потретє, мати можливість повернути бракований виріб з мінімальними матеріальними й моральними втратами (/з журналу). агентства.

Учням пропонують уявити, що вони працюють на посаді директора промислового підприємства чи рекламного

До вас на прийом прийшли керівники структурних підрозділів (відділів, цехів) для вирішення виробничих питань. Завершіть усно запропоновані репліки.

[? я сподівався почути від вас...

? Я підтримую вас і хотів би...

? Радив би вам...

? Мені здається, що...

글 Мені шкода, але...

[? Мені не подобається, що ви...

? Вибачте, але я мушу...

? Вважав би за необхідне нагадати вам...

?] Ще раз дякую і висловлюю надію..

Учні моделюють ситуації ділового спілкування, у яких були $б$ можливими деякі з наведених реплік.

- Ви спеціаліст фінансового відділу підприємства. Вам доручили повідомити ділового партнера про перенесення дати розрахунку за виконане замовлення на десять днів з незалежних від підприємства причин. Це потрібно зробити коректно, щоб діловий партнер не відмовився від подальшої співпраці.

- Складіть діалог з діловим партнером під час зустрічі в офісі вашого підприємства (6-8 реплік).

- Складіть діалог з діловим партнером під час спілкування з ним по телефону (6-8 реплік).

Проведений аналіз підручника «Українська мова. рівень стандарту ( автор - Авраменко О.) для учнів 10 класу закладів загальної середньої освіти (Авраменко О., 2018) засвідчує наявність, зокрема, таких вправ-спостережень:

- Прочитайте діалог і розкажіть, через що виникло непорозуміння.

У київському супермаркеті.

Касирка: 3 Вас 690 рублів.

Покупець (розгублено): Але я не маю рублів...

Касирка (з люттю в голосі): А як можна йти до магазину без грошей?

Покупець (жартівливо): А гривнями розрахуватися можна?

Касирка (з обуренням): Ви знущаєтеся? Давайте гривні й не морочте мені голову!

- Розгляньте світлини з назвами київських кав'ярень і виконайте завдання.

А. Поміркуйте, чому українські підприємці дають своїм закладам громадського харчування переважно іншомовні назви. Причиною схиляння перед чужоземним, на вашу думку, $є$ рабська психологія власників, їхній комплекс меншовартості чи, може, щось інше? Викладіть свої роздуми письмово (п'ять-сім речень).

Б. Запропонуйте в роздумі свої назви кав'ярень, використавши власне українську лексику.

3 майбутніми вчителями обговорюємо різні варіанти виконання пошуково-дослідницьких, творчих завдань, добираємо переконливі аргументи для доведення власної думки, навчаємося застосовувати набуті уміння в різних життєвих і навчальних ситуаціях спілкування, доцільно користуватися комунікативними стратегіями та стратегіями співпраці, вивчаємо досвід педагогів. О.Галамай, учителька української мови та літератури НВК «Школа-гімназія І-ІІІ ступенів ім. Блаженного Климентія і Андрея Шептицьких», м. Львова (Уроки з підприємницьким тлом, 2014), наприклад, ознайомлює учнів 9 класу з текстом про визначного підприємця та мецената, почесного громадянина м. Львова Володимира Кашицького та його життєвий успіх. Він переїхав до Львова 1992 року, відкривши тут піцерію і кав'ярню «Кастелярі». Долаючи труднощі, розвинув своє підприємництво, став одним із найбільших українських меценатів, реалізуючи своє кредо: «Заробляю, щоб давати». Підтримував українські культурні заходи, громадські організації (Народний Рух України, фестиваль «Червона рута», товариство «Надсяння» та ін..). Фінансував видання понад 30 книжок; подарував для школи бандуристів будинок у м.Ірпінь під Києвом. Підтримував матеріально тих, хто був у потребі. Кашицький любив повторювати, що досягає успіху, тому що він українець. «Історія України дає безліч прикладів, коли гору брала не сила м'язів, а сила духу, енергія думки».

Н. Данилів, учителька української мови та літератури м. Львова (Уроки з підприємницьким тлом, 2014), спонукає учнів до вивчення і повторення відокремлених членів речення та особливостей публіцистичного стилю мовлення через складання презентації реклами сучасного мобільного телефона або потреби сортувати сміття. Отже, слушно зауважує І.Синя (Уроки з підприємницьким тлом, 2014), уроки з підприємницьким тлом - це «дієвий метод розвитку індивідуальних здібностей учнів, сприяє бути успішними, кмітливими, творчо мислити, використовувати власні комунікативні навички для професійного зростання, а також відчувати міцні зв'язки між школою і потребами сьогодення (цього, погодьтеся, не вистачає українській освіті). А вчитель, своєю чергою, користаючи з синергії поєднання мови / літератури й підприємництва, зможе якісніше реалізувати мету та поставлені цілі, активізувати зацікавлення дітей до власного предмету».

\section{ВИСНОВКИ ТА ПЕРСПЕКТИВИ ПОДАЛЬШОГО ДОСЛІДЖЕННЯ}

Проведене дослідження дає підстави зробити такі висновки. В умовах реформування загальної середньої освіти й утвердження особистісно орієнтованої моделі освіти актуалізується потреба уведення до професійно орієнтованих, методичних дисциплін теми «Ключові компетентності школяра Нової української школи», 3-поміж яких важливе місце відведено підприємницькій компетентності або компетентності «ініціативність і підприємливість». У мовно-методичній підготовці майбутніх учителів-словесників важливо акцентувати увагу на європейські та українські законодавчо- 
нормативні освітні документи шкільні програми та методичного забезпечення уроків української мови, запропонованого для реалізації наскрізної лінії «Підприємливість і фінансова грамотність» та формування компетентності «ініціативність і підприємливість».

В європейських документах підкреслюється потреба в розробці спільного концептуального підходу різних країн щодо поняття підприємливості на європейському рівні як поняття, що ґрунтується на створенні культурної, соціальної чи економічної цінності. В українських законодавчо-нормативних освітніх документах та шкільних програмах уживані терміни «підприємливість та фінансова грамотність», «ініціативність і підприємливість»; ідеться про ініціативність, спроможність використовувати можливості та реалізовувати ідеї, перетворюючи їх на цінності для інших, уміння вирішувати проблеми, готовність брати відповідальність за власні рішення, здатність працювати в команді заради планування та здійснення проєктів, які мають культурну, суспільну або комерційну цінність; до навчальних ресурсів віднесено тексти офіційно-ділового стилю (резюме, доручення тощо), самопрезентації, зразки реклами, літературні твори, які містять моделі ініціативності. Проведений аналіз засвідчує, що методики формування фахової компетентності з основ підприємництва пропонуються переважно для майбутніх учителів технологій та математики і загалом відсутні для вчителів гуманітарних дисциплін.

На основі дослідної роботи, що проводиться зі студентами, з'ясовано, що в деяких підручниках з української мови для учнів 10 класу наявні завдання (виконання міжпредметних навчальних проектів, робота з різними джерелами інформації, робота з текстом, спостереження, діалоги), мета виконання - сприяти формуванню умінь генерувати нові ідеї й ініціативи та втілювати їх у життя з метою підвищення як власного соціального статусу та добробуту, так і розвитку суспільства і держави; ефективно використовувати індивідуальні заощадження, приймати доцільні рішення і брати на себе відповідальність, формувати моделі поведінки, необхідні для успішного розв'язання нагальних виробничих проблем. Вивчення досвіду вчителів переконує, що такі уроки $є$ дієвим методом розвитку індивідуальних здібностей учнів, формування міцних зв'язків між школою і потребами сьогодення.

Перспективним напрямом подальшого дослідження буде аналіз виконаних студентами проектів, спрямованих на формування в учнів основ підприємливості та ініціативності.

\section{Список використаних джерел}

1. Гончаренко Л. А. Підготовка вчителів-словесників до формування в учнів підприємницької компетентності. Таврійський вісник освіти. 2016. № 2 (54). С. 74-77.

2. Державний стандарт базової і повної загальної середньої освіти. URL: http://zakon2.rada.gov.ua/laws/show/13922011.

3. Державний стандарт базової середньої освіти. Проект. URL: https://mon.gov.ua/ua/news/ministerstvo-osviti-i-naukiukrayini-proponuye-dlya-gromadskogo-obgovorennya-proyekt-derzhavnogo-standartu-bazovoyi-serednoyi-osviti.

4. Майковська В. І. Проблеми формування підприємницької компетентності в українській освіті. Всеукраїнський науковий збірник: Наукові праці вищого навчального закладу «Донецький національний технічний університет». Серія: «Педагогіка, психологія і соціологія». 2017. № 1 (20). С. 73-80.

5. Назаренко Г. А. Формування підприємницької компетентності учнів загальноосвітніх навчальних закладів у відповідності до вимог нових державних стандартів. Черкаси : ЧОІПОПП, 2014. 68 с.

6. Про освіту: Закон України від 05.09.2017 р. № 2145-VIII. Відомості Верховної Ради (BBP). 2017. № 38-39. C. 380. URL: http://zakon2.rada.gov.ua/laws/show/2145-19/page.

7. Програма «Українська мова. 10-11 класи». URL: https://mon.gov.ua/ua/osvita/zagalna-serednya-osvita/navchalniprogrami/navchalni-programi-dlya-10-11-klasiv.

8. Семеног О. М. Концепт «підприємницька компетентність» у вимірах лінгвопраксеології. Педагогічні науки: теорія, історія, інноваційні технології. 2018. № 6 (80). С. 263-272.

9. Уроки з підприємницьким тлом : Навчальні матеріали. заг. ред. Е. Бобінська, Р. Шиян, М. Товкало. Варшава: Сова, 2014. URL: http://sae-ukraine.org.ua/ua/resource/uroki_z_pidpriemnytskim_tlom.

10. Українська мова. 5-9 класи. Програма для загальноосвітніх навчальних закладів з українською мовою навчання. Київ: Видавничий дім «Освіта», 2013. URL: https://mon.gov.ua/ua/osvita/zagalna-serednya-osvita/navchalniprogrami/navchalni-programi-5-9-klas.

11. Українська мова 10-11 класи. Програма для профільного навчання учнів загальноосвітніх навчальних закладів. Інформаційний збірник та коментарі Міністерства освіти і науки України. 2017. № 12. С. 3-73.

12. Заболотний О. В., Заболотний В. В. «Українська мова. Підручник для учнів 10 класу закладів загальної середньої освіти. URL: https://bit.ly/2zekYmO.

13. Авраменко О. Українська мова. Підручник для учнів 10 класу. URL: https://lib.imzo.gov.ua/handle/123456789/80.

14. Key Competencies. An Overarching Frame of Reference for an Assessment and Research Program. OECD (Draft). URL: http://www.deseco.admin.ch.

15. Bacigalupo M., Kampylis P., Punie Y., Van den Brande G. EntreComp: The Entrepreneurship Competence Framework. Luxemburg: Publication Office of the European Union. $2016 . \quad$ URL: http://ipq.org.ua/upload/files/files/03_Novyny/2016.07.8-9_EntrComp/EntreCompFramework\%20UKR.pdf.

\section{References}

1. Honcharenko, L. A. (2016). Pidhotovka vchyteliv-slovesnykiv do formuvannia v uchniv pidpryiemnytskoi kompetentnosti [Preparation of vocabulary teachers for the formation of entrepreneurial competence of students.]. Tavriiskyi visnyk osvity. 2016. № 2 (54), 74-77.

2. Derzhavnyi standart bazovoi i povnoi zahalnoi serednoi osvity [The state standard of basic and complete general secondary education]. URL: http://zakon2.rada.gov.ua/ laws/show/1392-2011. 
3. Derzhavnyi standart bazovoi osvity. Proekt [The state standard of basic education. Project]. URL: https://mon.gov.ua/ua/news/ministerstvo-osviti-i-nauki-ukrayini-proponuye-dlya-gromadskogo-obgovorennya-proyektderzhavnogo-standartu-bazovoyi-serednoyi-osviti.

4. Maikovska, V. I. (2017). Problemy formuvannia pidpryiemnytskoi kompetentnosti v ukrainskii osviti [Problems of formation of entrepreneurial competence in Ukrainian education]. Vseukrainskyi naukovyi zbirnyk: Naukovi pratsi vyshchoho navchalnoho zakladu «Donetskyi natsionalnyi tekhnichnyi universytet». Seriia: «Pedahohika, psykholohiia i sotsiolohiia». 2017. № 1 (20), 73-80.

5. Nazarenko, H. A. (2014). Formuvannia pidpryiemnytskoi kompetentnosti uchniv zahalnoosvitnikh navchalnykh zakladiv u vidpovidnosti do vymoh novykh derzhavnykh standartiv [Formation of entrepreneurial competence of students of secondary schools in accordance with the requirements of the new state standards]. Cherkasy : ChOIPOPP, 2014.

6. Pro osvitu [About Law] (2017). Zakon Ukrainy. № 2145-VIII. Vidomosti Verkhovnoi Rady. 2017. № 38-39, 380. URL: http://zakon2.rada.gov.ua/laws/show/2145-19/page.

7. Prohrama "Ukrainska mova. 10-11 klasy" [The program "Ukrainian language. Grades 10-11"]. URL: https://mon.gov.ua/ua/osvita/zagalna-serednya-osvita/navchalni-programi/navchalni-programi-dlya-10-11-klasiv.

8. Semenog, O. M. (2018). Kontsept «pidpryiemnytska kompetentnist» u vymirakh linhvoprakseolohii [The concept of "entrepreneurial competence" in the dimensions of linguopraxology.]. Pedahohichni nauky: teoriia, istoriia, innovatsiini tekhnolohii. 2018. № 6 (80), 263-272.

9. Uroky z pidpryiemnytskym tlom [Lessons with an entrepreneurial background]. Navchalni materialy. zah. red. E. Bobinska, R. Shyian, M. Tovkalo. Varshava: Sova, 2014. URL: http://sae-ukraine.org.ua/ua/resource/uroki_z_pidpriemnytskim_tlom.

10. Ukrainska mova. 5-9 klasy. Prohrama dlia zahalnoosvitnikh navchalnykh zakladiv z ukrainskoiu movoiu navchannia [Ukrainian language. 5-9 classes. Program for comprehensive educational institutions with Ukrainian language of instruction]. Kyiv: Vydavnychyi dim «Osvita», 2013. URL: https://mon.gov.ua/ua/osvita/zagalna-serednya-osvita/navchalniprogrami/navchalni-programi-5-9-klas.

11. Ukrainska mova 10-11 klasy. Prohrama dlia profilnoho navchannia uchniv zahalnoosvitnikh navchalnykh zakladiv [Ukrainian language grades 10-11. Program for profile education of students in secondary schools]. Informatsiinyi zbirnyk ta komentari Ministerstva osvity i nauky Ukrainy. 2017. № 12, 3-73.

12. Zabolotnyi O. V., Zabolotnyi V. V. Ukrainska mova. Pidruchnyk dlia uchniv 10 klasu zakladiv zahalnoi serednoi osvity [Ukrainian language. Textbook for students of the 10th grade of general secondary education institutions]. URL: https://bit.ly/2zekYmo.

13. Avramenko O. Ukrainska mova. Pidruchnyk dlia uchniv 10 klasu [Ukrainian language. A textbook for students of the 10th grade.]. URL: https://lib.imzo.gov.ua/handle/123456789/80.

14. Key Competencies. An Overarching Frame of Reference for an Assessment and Research Program. OECD (Draft). URL: http://www.deseco.admin.ch.

15. Bacigalupo M., Kampylis P., Punie Y., Van den Brande G. (2016). EntreComp: The Entrepreneurship Competence Framework. Luxemburg: Publication Office of the European Union. $2016 . \quad$ URL: http://ipq.org.ua/upload/files/files/03_Novyny/2016.07.8-9_EntrComp/EntreCompFramework\%20UKR.pdf.

\section{METHODICAL PREPARATION OF FUTURE LANGUAGE-TEACHERS FOR THE STUDENTS' ENTREPRENEURSHIP AND INITIATIVE BASIS FORMATION Olena Semenog}

A.S. Makarenko Sumy State Pedagogical University, Ukraine

Abstract. The scientific researches on methodical preparation of future language-teachers for realization the content line "Entrepreneurship and financial literacy" at the lessons of the Ukrainian language at the high school is carried out in the article. Also, the article deals with the formation of one of the key competences of entrepreneurship.

Formulation of the problem. According to the Article 12 of the Law of Ukraine "About Education" (2017), the purpose of complete secondary education is defined as the comprehensive development, education and socialization of a person who is able to live in society and civilized interaction with nature, has a desire for self-improvement and lifelong learning, conscious life choices and self-fulfillment, responsibility, work and civic activity. The achievement of the goal is ensured through the content lines of school curricula with all primary subjects, including "Entrepreneurship and Financial Literacy". It is proposed to implement the defined cross-cutting content line by forming one of the key competencies necessary for successful life - the "initiative and entrepreneurship competence". The implementation of the cross-cutting content line "Entrepreneurship and financial literacy" into such subjects as "Ukrainian language" and "Ukrainian literature" involves the implementation of cross-curricular educational projects, the students work with different sources of information to form clearly speaking skills, present their plans, resolve conflict situations, make decisions, take responsibility, and formulate the behaviors needed to successfully solve industrial problems. Such requirements require from language-teachers constant personal and professional development and self-development, which at the stage of study in higher pedagogical education institutions is ensured by introducing into the vocationally-oriented and methodical subjects the topics like "Key competences of the student of the New Ukrainian School".

Materials and methods. Theoretical and empirical methods: analysis, generalization and systematization of reference, scientific sources in order to clarify the essence of key concepts, identify the state of problem development.

Results. Emphasis is placed on particular aspects of the methodological preparation of future language-teachers for the formation of the basics of entrepreneurship and initiative. European and Ukrainian legislative and normative educational documents were summarized. School programs and methodological papers of some Ukrainian textbooks for 10th grade students offered for the implementation the line "Entrepreneurship and financial literacy" and formation of "initiative and entrepreneurship" competence were analyzed.

Conclusions. In the context of reforming general secondary education and the adoption of a personally oriented model of education, it is actualized the need to introduce into the vocationally oriented, methodical disciplines the topic "Key competences of a student of the New Ukrainian School", among which the importance of "entrepreneurial and initiative" competence are very important.

Key words: language-methodical course, future language-teachers, student, high school, lesson of Ukrainian language, institution of higher pedagogical education, school program, textbook on Ukrainian language, entrepreneurial competence of the student, competence "entrepreneurship and initiative". 